
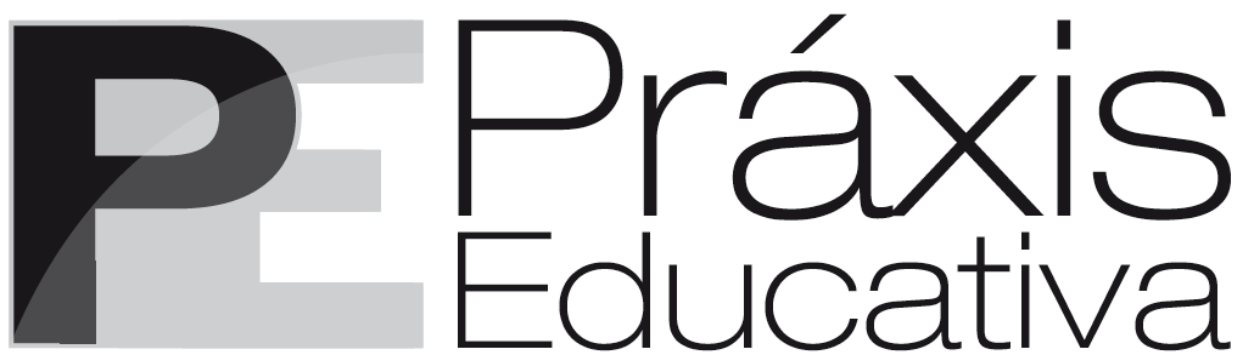

ISSN 1809-4031

eISSN 1809-4309

https://doi.org/10.5212/PraxEduc.v.15.15264.052

\title{
A diretriz de educação literária na Política Nacional de Alfabetização: contrapontos
}

\section{The literary education guideline in the National Literacy Policy: counterpoints}

\section{La directriz de educación literaria en la Política Nacional de Alfabetización: contrapuntos

\author{
https://orcid.org/0000-0002-6933-6552
} \\ Mariana Passos Ramalhete*}

\begin{abstract}
Resumo: Este artigo, ancorado na perspectiva bakhtiniana enunciativa-discursiva da linguagem, objetiva refletir como a diretriz de educação literária é abordada na Política Nacional de Alfabetização (PNA) e em que medida se configura como uma concepção afim ao ideário neoliberal gestor de sua implementação. A partir de uma análise documental, debruça-se sobre o "Caderno da PNA", oficializado em 2019. Neste texto, pondera-se que essa é uma política de governo, marcada pelo recrudescimento da desigualdade social, do retrocesso e do ultraconservadorismo, que rejeita o debate público inerente à democracia e fere a dimensão crítica da alfabetização. Conclui-se que essa diretriz se fundamenta em uma política pública neoliberal que fragiliza a possibilidade de uma educação literária crítica e, assim, priva, sobretudo, sujeitos em processo de alfabetização, de um direito inalienável: a Literatura.
\end{abstract}

Palavras-chave: Educação literária. Políticas públicas educacionais. PNA.

Abstract: This paper, anchored in the enunciative-discursive Bakhtinian perspective of language, aims to reflect how the guideline of literary education is approached in the National Literacy Policy (Politica Nacional de Alfabetização - PNA) and to what extent it is configured as a conception related to the neoliberal ideology that manages its implementation. Based on a documental analysis, the focus is on the "Caderno da PNA" (PNA Guideline booklet), made official in 2019. In this text, it is considered that this is a government policy, marked by the upsurge in social inequality, retrogression and ultraconservatism, which rejects the inherent public democracy debate and hurts the critical dimension of literacy. It concludes that its guideline is based on a neoliberal public policy that weakens the possibility of a critical literary education and, thus, deprives, especially subjects in the process of literacy, of an inalienable right: Literature.

Keywords: Literary education. Educational public policies. PNA.

\footnotetext{
* Professora do Instituto Federal de Educação, Ciência e Tecnologia do Espírito Santo (Ifes), campus Venda Nova do Imigrante. Doutora e Mestra em Educação pela Universidade Federal do Espírito Santo (Ufes). E-mail: $<$ marianaramalhete@yahoo.com.br>.
} 
Resumen: Este artículo, anclado en la perspectiva bakhtiniana enunciativa-discursiva del lenguaje, tiene como objetivo reflexionar sobre cómo la educación literaria es abordada en la Política Nacional de Alfabetización (PNA) y en qué medida se configura como una concepción afín al ideario neoliberal gestor de su implementación. A partir de en un análisis documental, se analiza el "Cuaderno de la PNA" (Caderno da PNA), oficializado en 2019. En este texto, se considera que ésta es una política de gobierno, marcada por el aumento de la desigualdad social, de la regresión y del ultraconservadurismo, que rechaza el debate público inherente a la democracia y perjudica la dimensión crítica de la alfabetización. Se concluye que esa directriz se basa en una política pública neoliberal que fragiliza la posibilidad de una educación literaria crítica y, por lo tanto, priva, sobre todo a los sujetos en el proceso de alfabetización, de un derecho inalienable: la Literatura.

Palabras clave: Educación literaria. Políticas públicas educativas. PNA.

\section{Considerações iniciais}

Este artigo é o desdobramento de uma pesquisa mais ampla ${ }^{1}$, cujo objetivo centrou-se na compreensão das concepções de leitura literária chanceladas em políticas públicas para a alfabetização no início do século XIX. A partir da análise de documentos oficiais do Programa de Formação de Professores Alfabetizadores (Profa), oferecido nos anos 2001 e 2002; do PróLetramento, implementado nos anos 2005, 2008 e do Pacto Nacional pela Alfabetização na Idade Certa (Pnaic), concretizado entre os anos de 2012 e 2018, confirmou-se que esses programas resguardam proximidades.

Essas políticas oficiais, influenciadas por organismos de diretrizes internacionais (GONTIJO, 2014; MORTATTI, 2013), pautadas na pedagogia das competências e na dissociação entre alfabetização e letramento, reduzem a leitura literária a práticas utilitaristas e, apartadas de qualquer mediação consistente, nutrem uma ideia reducionista de leitura por diversão, por deleite e por prazer fugaz. Mesmo que façam menção à literatura, essas três políticas públicas (ainda que, como no caso do Pnaic, preocupe-se em distribuir obras literárias para as escolas), tratam o texto literário como algo lateral, periférico, apenas como ornamento nos momentos de formação. Desse modo, o aparente modo lúdico e inofensivo com o qual é engendrada a leitura literária nesses programas, mesmo que sob o epíteto de contribuição para formação de leitores/as, bem como de rejeição ao analfabetismo, confirmam, paradoxalmente, a palidez da própria refutação e, desse modo, colaboram para consolidar, ainda mais, a precariedade das políticas oficiais de governo para o campo da alfabetização no Brasil (RAMALHETE, 2019).

A descontinuidade é característica das políticas públicas educacionais brasileiras, visível, sobretudo, na meta, sempre adiada, de eliminação do analfabetismo e universalização do Ensino Fundamental. Como um óbice, essa chaga impossibilita que se enrijeça uma orientação orgânica e contínua à atividade educativa, exigência intrínseca ao próprio conceito de sistema nacional de educação (SAVIANI, 2008, 2010, 2012). A maioria das políticas é demolida por administrações posteriores, empenhadas em imprimir sua própria marca ou em destruir o que havia sido feito em governos pregressos (CUNHA, 1991). Não por acaso, nas duas primeiras décadas deste século, este país já entrou em sua quarta política educacional para o campo da alfabetização.

A política para a alfabetização em vigor, intitulada Política Nacional de Alfabetização (PNA), foi instituída pelo Decreto No 9.765, de 11 de abril de 2019 (BRASIL, 2019a). Ela integra um projeto político-ideológico neoliberal e ultraconservador e está estrategicamente articulada a outras medidas de aniquilamento dos avanços democráticos conquistados pela população brasileira nas últimas décadas (MORTATTI, 2019a). O documento defende termos como a "literacia" e, sob

\footnotetext{
1 Trata-se da tese de Doutorado Leitura literária em programas governamentais de formação de professores alfabetizadores do início do século XXI (2001-2018): o tropeço, a trapaça e o deleite (RAMALHETE, 2019).
}

Práxis Educativa, Ponta Grossa, v. 15, e2015264, p. 1-21, 2020 Disponível em: <https://www.revistas2.uepg.br/index.php/praxiseducativa> 
um ilusório discurso inovador, enfatiza e defende com robustez o método fônico; conserva o ideário neoliberal das "habilidades" e das "competências"; despreza o trabalho docente de mediação; e corrói os delineamentos de uma educação democrática, de qualidade, laica e socialmente referenciada.

A PNA prevê, em uma de suas diretrizes, a formação de uma “educação literária"”. Quanto a esse aspecto, é preciso considerar pelo menos três norteamentos basilares: a) a construção de uma educação literária relevante envolve a definição de objetivos, de métodos e de formas de avaliação coerentes com o processo de produção do conhecimento, de modo a educar os cidadãos, também por meio do texto literário, rumo à conscientização de seu lugar social (LEAHY-DIOS, 2004); b) a educação literária destina-se à confrontação de como foram construídos e interpretados as ideias e os valores que se instauram na cultura (COLOMER, 2007); e c) a educação literária efetiva não se restringe ao ensino de literatura ou à leitura de textos literários. Perpassa campos (estético, filosófico, científico) que se intercambiam. No caso da escola, o trabalho educativo também tem como meta defrontar o sujeito com a complexidade (cultural, social, histórica, econômica, dentre outras) das práticas concernentes ao literário, a fim de que haja a compreensão de que a literatura não se abrevia à escrita e à leitura de obras. Ademais, a educação literária perpassa essencialmente a luta pela mudança das condições de vida em sentido mais amplo, pois a literatura inexiste apartada de um sistema econômico, social, político e cultural (DALVI, 2018a, 2018b, 2018c).

Destarte, a partir de uma análise documental e ancorado na perspectiva (enunciativadiscursiva da linguagem) bakhtiniana, este artigo objetiva refletir como a diretriz de educação literária é abordada na PNA e em que medida se configura como uma concepção afim ao ideário neoliberal gestor de sua implementação. Debruça-se sobre o "Caderno da PNA" (BRASIL, 2019b), lançado em 15 de agosto de 2019 e produzido pela Secretaria de Alfabetização (Sealf) do Ministério da Educação (MEC). Para alcance de tal intento, além das considerações iniciais e finais, este artigo abordará o contexto de implementação dessa política educacional, a partir de recuperação de dados mais recentes de ações provenientes do Governo Federal no âmbito da educação; em seguida, apresentará em que consiste a PNA, para que seja possível, então, tecer algumas análises acerca da educação literária proposta pelo programa.

\section{O contexto de implementação da PNA}

A percepção da singularidade de um documento exige a reunião de um conjunto de aspectos que engloba, pelo menos, a identificação e o lugar social ocupado por quem o assina; a percepção de como, por que, sob qual(is) demanda(as) e movido por qual(is) intencionalidade(s) o documento foi produzido; o reconhecimento do público-alvo principal e o contexto histórico da implementação. Isso porque a linguagem é "[...] o produto da atividade bumana coletiva e reflete em todos os seus elementos tanto a organização econômica como a sociopolítica da sociedade que a gerou" (VOLÓCHINOV, 2013, p. 141, grifo do autor). Ela (a linguagem) tem natureza social e é materializada em enunciados. Assim, é no mínimo equivocado isolar uma política educacional de seu contexto de produção. Nesse sentido, esta seção dedica-se a responder à seguinte pergunta: a PNA foi inaugurada em qual momento histórico da educação brasileira?

O início dos anos 1990 foi assinalado por transformações na área cultural, tecnológica e, especialmente, no que tange ao âmbito econômico-político, tornou-se mais evidente o avanço do

\footnotetext{
2 Apesar dos inúmeros trabalhos que citam o termo "educação literária", as referências citadas foram elencadas por causa da necessidade de uma delimitação um pouco mais acurada e precisa do termo "educação literária" em pesquisas mais recentes.
}

Práxis Educativa, Ponta Grossa, v. 15, e2015264, p. 1-21, 2020 
neoliberalismo. Marcado por uma agenda que engloba severos ajustes fiscais, privatização de empresas e serviços públicos, crítica à democracia, tais práticas foram rapidamente incorporadas às políticas de países latino-americanos. Nessa configuração, no âmbito educacional, as ideias pedagógicas exacerbam um discurso de fracasso da escola pública e da ineficiência estatal na busca de um bem comum. Advoga-se a favor da iniciativa privada, orquestrada hábil e nocivamente pelas leis do mercado (SAVIANI, 2013). Esses efeitos, ainda em vigor no contexto atual, contribuem para a expansão do fosso entre marginados e abastados (IBARRA, 2011).

No governo atual (2019-?), os ataques frontais à educação solidificam-se à medida que o exercício de cargos importantes é feito exatamente por aqueles que parecem querer sepultá-la. A gestão do ex-ministro Ricardo Vélez Rodríguez foi caracterizada, em linhas gerais, pela ofensa a brasileiros/as, comparando-os a canibais (FOLHA DE SÃO PAULO, 2019); pelo combate ao chamado "marxismo cultural" e "ideologia de gênero" (SALDAÑA, 2019); pela defesa do homeschooling (educação doméstica) e da interferência religiosa na educação (RONZANI, 2019); pela publicização de um completo desconhecimento de políticas educacionais da área da alfabetização vislumbradas desde a defesa do método fônico (MORENO, 2019) ao descontrole acerca das medidas avaliativas na área da alfabetização (MARIZ; FERREIRA, 2019); pela extinção da Secretaria de Educação Continuada, Alfabetização, Diversidade e Inclusão Social (Secadi), que tinha como foco ações e políticas que valorizassem a diversidade e a inclusão, atuando especificamente nos seguintes âmbitos: Educação Especial, Educação de Jovens e Adultos, Educação do Campo, Educação Escolar Indígena, Educação Escolar Quilombola, Educação para as relações Étnico-Raciais e Educação em Direitos Humanos (BRASIL, 2018); e pelo revisionismo histórico acerca da Ditadura Militar brasileira (EL PAÍS, 2019).

Demitido em pouco mais de 90 dias de governo (1 de janeiro de 2019 a 8 de abril de 2019), Vélez foi substituído por Abraham Bragança de V. Weintraub, até então secretário-executivo da Casa Civil. Desde então, sua gestão tem sido balizada pela incitação popular ao desprezo pelo saber elaborado, à aversão à área das humanidades pela tentativa, por exemplo, de extinção dos cursos de Sociologia e Filosofia (BASILIO, 2019), à perseguição aos/às professores/as (BOGHOSSIAN, 2019) e às instituições federais de educação. Em pouco tempo de governo, além do menosprezo à ortografia (NICOLETI, 2019), o atual ministro anunciou a revisão do Plano Nacional de Educação - PNE (MUGNATTO, 2019), o que se caracteriza como uma forja para o descumprimento do referido plano, que inclui o destino de $10 \%$ do PIB brasileiro à educação. Congelou verbas destinadas à Educação Básica (ESTADÃO CONTEÚDO, 2019; PALHARES, 2019) e às universidades (ANDES, 2019). Com isso, o MEC confina instituições, erigidas pelo tripé do ensino, da pesquisa e da extensão, que, em muitos estados, ofertam atendimento de saúde à população por meio de hospitais universitários, ao funcionamento com o pouco, com a escassez, com a falta. Atrelada a essa asfixia, além do corte de bolsas para pesquisa em todo o país (PINHO; SALDAÑA; GENTILE, 2019), medida que esfacela a produção científico-tecnológica brasileira, e da extinção do programa "Idioma sem Fronteiras" (REVISTA FÓRUM, 2019), foi lançado o programa "Future-se", que, sob a alegação de consulta pública e modernização das universidades (BRASIL, 2019d), é a marca das garras da privatização nas instituições federais (MIGUEL, 2019).

Em julho de 2019, de forma antidemocrática, o MEC extinguiu do Conselho Consultivo do Plano Nacional do Livro e Leitura (BRASIL, 2019c), o que fez alterar o Decreto $\mathrm{N}^{\circ}$ 7.559, de 1 de setembro de 2011, que dispõe sobre o Plano Nacional do Livro e Leitura - PNLL (BRASIL, 2011). Em outras palavras, acaba com a representatividade de instâncias que corroboram com o planejamento de estratégias para o incentivo à leitura no país. Até julho de 2019, 17 Conselhos tiveram a representatividade solapada (ANDRADE, 2019). Antes da extinção, esses 17 colegiados somavam 201 vagas com membros das mais variadas instâncias sociais que colaboravam na elaboração e na implementação de políticas públicas. Os Decretos reduziram quase pela metade a 
participação de representantes da sociedade civil, perfazendo um total de 104 vagas. O desmonte segue com recrudescimento de movimentos (também antidemocráticos) tais como Escola sem Partido, os ataques à União Nacional dos Estudantes (UNE), ao Professor Paulo Freire (patrono da educação brasileira), e o anúncio de promessa de limpeza (ideológica) em livros didáticos de história (CARTA CAPITAL, 2020). Em meio à pandemia do coronavírus (Covid-19), a fixação, sem consulta pública, de novos critérios de distribuição de bolsas para Programas de PósGraduação (BRASIL, 2020a), retirou abruptamente o investimento em pesquisa de centenas de estudantes de Mestrado e Doutorado em todo o país. Em movimento semelhante, o Conselho Nacional de Desenvolvimento Científico e Tecnológico (CNPq) direcionou as bolsas de Programas de Bolsas de Iniciação Científica (PIBICs) para as áreas denominadas "tecnologias prioritárias" (CNPQ, 2020b). Na prática, em atendimento às Portarias No 1.122, de 19 de março de 2020 e $\mathrm{N}^{\circ}$ 1.329, de 27 de março 2020 (BRASIL, 2020c, 2020d), é a extinção de investimento público para pesquisas nos campos das Ciências Humanas, Ciências Sociais Aplicadas, Linguística, Letras e Artes.

Mortatti (2019a) assegura que a gestão federal hodierna tem nutrido uma mentalidade colonizada, com avanço do nacionalismo de extrema-direita. Acrescenta que o Ministério da Educação, além de ser gerido por pessoas indicadas pelo autointitulado filósofo Olavo de Carvalho, em consonância com políticas neoliberais, concede livre acesso, por exemplo, à Associação Nacional de Universidades Privadas (Anup), instância representativa de interesses de grandes monopólios educacionais privados tais como Kroton, Estácio, Anhanguera, Pitágoras e Uninove, cuja presidência é exercida por Elizabeth Guedes, irmã do Ministro da Economia Paulo Guedes.

Não há relações dialógicas da língua, se ela for apartada da realidade (BAKHTIN, 2015). Para que o dialogismo ocorra, é preciso que os enunciados, a unidade real da comunicação verbal (VOLÓCHINOV, 2017), estejam contemplados dentro da esfera do discurso e das relações sociais. É apenas nessa conjuntura que é possível responder, refutar, confirmar, antecipar, confrontar posições e refletir sobre elas, lançar questionamentos, rejeitar ou aceitar a palavra do outro. A PNA, gestada nos moldes do conservadorismo, pauta-se na égide de uma neutralidade falaciosa (MORTATTI, 2019a). É nesse contexto educacional, também direcionado pela Base Nacional Comum Curricular (BNCC), e severamente vitimado pela Emenda Constitucional No 95, de 15 de dezembro de 2016, que estabeleceu um novo regime fiscal (BRASIL, 2016) e congelou os investimentos em educação e saúde por 20 anos, que se pode, então, tentar refletir como a educação literária é proposta por essa nova política pública.

\section{A educação literária na PNA}

Para que seja possível compreender a abordagem da educação literária na PNA, é necessário, antes de tudo, mencionar a constituição do documento em sua totalidade. Volóchinov (2017, p. 181, grifo do autor) afirma que: "A palavra está sempre repleta de conteúdo e de significação ideológica ou cotidiana". Para o filósofo, tudo o que se escuta ou profere não é puramente "palavra", mas algo bom ou mal, relevante ou irrelevante, mentira ou verdade. Uma vez que inexiste neutralidade nos enunciados, inclusive os de teor analítico, qualquer ação governamental deve ser posta sob suspeita.

O Caderno da PNA é destinado a estados e municípios, professores/as e alunos/as do Ensino Fundamental, pais e responsáveis, bem como estudantes da Educação de Jovens e Adultos (PERA, 2019). Com 56 páginas, o documento é constituído por uma nota introdutória do ministro da Educação. Nela, ele expõe o desempenho do Brasil em avaliações de larga escala. O ministro sugere que indicadores como esses demandam ações governamentais em prol de "reflexos positivos", assentadas, sobretudo, na "ciência cognitiva da leitura". Em seguida, é exposto um texto 
de Carlos Francisco de Paula Nadalim, Secretário de Alfabetização, em que são listadas as instâncias que deram subsídio à construção do documento e a defesa da "ciência cognitiva da leitura", que, na visão do secretário, apresenta um conjunto vigoroso de evidências sobre como as pessoas aprendem a ler e a escrever e indica os caminhos mais eficazes para o ensino da leitura e da escrita (BRASIL, 2019b).

Mais uma vez, essa alteração nas diretrizes do MEC, relativas à alfabetização, remete à crítica de Cunha (1991). Esse autor elenca o tripé que ampara a descontinuidade de políticas educacionais no Brasil: o eleitoralismo, o experimentalismo pedagógico e o voluntarismo ideológico. O primeiro diz respeito às políticas educacionais que são capazes de trazer resultados positivos nas urnas. O segundo aspecto é resultante do entusiasmo com propostas ancoradas não em bases científicas, mas, apressadamente, embebidas de um discurso redentor dos problemas educacionais. Por fim, o voluntarismo ideológico circunscreve-se em um posicionamento salvacionista, baseado em uma proposição de aniquilamento dos males da educação escolar e, quiçá da sociedade, no exíguo espaço de uma administração, ou até em menos tempo. Dessa maneira, com a menção a avaliações internacionais, a instâncias educacionais representativas e a palavras do campo científico (evidências, pesquisadores, especialistas, dentre outras), almeja-se reforçar a ideia de credibilidade e de aparente consenso entre o meio acadêmico e representativo quanto às práticas destinadas ao campo da alfabetização. Todo o documento reitera insistentemente o termo "evidências científicas" (16 recorrências). Sob uma aparência de respaldo científico, essa estratégia, em consonância com os delineamentos de um voluntarismo ideológico anunciado por Cunha (1991), destina-se a uma perseguição política e ideológica, usada como escudo para proteção de "cavaleiros" na cruzada ideológica, cuja finalidade é salvar a alfabetização, a partir do esfacelamento simbólico e político dos inimigos (compreendendo também a participação pública), que representam ameaça ao Estado brasileiro (MORTATTI, 2019a).

O documento é composto por uma contextualização, que compreende alguns marcos legais e históricos sobre a alfabetização. Nele, há uma seção dedicada à distinção de conceitos, tais como alfabetização, literacia e numeracia, seguida de orientações para o aprendizado da leitura e para escrita, tanto para crianças, como para adultos. São listados os princípios, os objetivos e as diretrizes da PNA, bem como as instâncias de controle e de monitoramento dos resultados. Por fim, cita as referências, cuja essência é majoritariamente estrangeira, o que mostra uma postura colonizada (MORTATTI, 2019a) e, ao mesmo tempo, incongruente, visto que o governo sustenta a bandeira do patriotismo.

O problema principal não repousa no alicerce em referenciais estrangeiros, mas a qual demanda, intencionalidade e filiação teórica esses referenciais estão submissos. As fundamentações teóricas eleitas são reflexo de um determinado discurso científico-acadêmico e ostentam um posicionamento político. Configuram-se também como propaganda demagógica, tendo em vista que a base de sustentação gnosiológica do Governo Federal aparenta ter aversão à ciência e à fortuna teórica e crítica acumulada por décadas de discussão coletiva nos mais diversos fóruns da área. Nesse sentido, o Estado, como agente regulador de políticas públicas, alimenta oportunamente um interesse particular, ao ignorar, por exemplo, todo um percurso de trabalho e crítica acumulado por pesquisas nacionais acerca da alfabetização ${ }^{3}$; assumindo um posicionamento

\footnotetext{
3 Nesse sentido, cabe citar a obra de Paulo Freire e, também, os trabalhos oriundos de pesquisas do GT-10 (Alfabetização, Leitura e Escrita) da Associação Nacional de Pós-Graduação e Pesquisa em Educação (ANPEd); da Associação Brasileira de Alfabetização (Abalf); do Núcleo de Estudos e Pesquisas em Alfabetização, Leitura e Escrita do Espírito Santo (Nepales), com sede na Universidade Federal do Espírito Santo (Ufes); do Grupo de Pesquisa Alfabetização, Leitura e Escrita/Trabalho Docente na Formação Inicial (ALLE/AULA), sediado na Universidade Estadual de Campinas (Unicamp); também do grupo de pesquisa História da Alfabetização, Leitura, Escrita e dos Livros Escolares (Hisales), da Universidade Federal de Pelotas (UFPel); dentre outros.
}

Práxis Educativa, Ponta Grossa, v. 15, e2015264, p. 1-21, 2020 Disponível em: <https://www.revistas2.uepg.br/index.php/praxiseducativa> 
monofônico (BAKHTIN, 2013) e ahistórico, rechaça o amplo debate necessário à implementação de políticas educacionais e à manutenção da democracia.

Oliveira (2011) faz uma distinção entre políticas de governo e políticas de Estado. As políticas de governo visam a responder às demandas de uma agenda política interna e são decididas pelo Executivo, a partir de um processo de formulação e de implementação de medidas e de programas. As políticas de Estado, por sua vez, contemplam mais de uma agência do Estado. Abrangem instâncias diversas de discussão e resultam em mudanças de normas ou disposições preexistentes (OLIVEIRA, 2011). Embora haja, no calor dos acontecimentos, o risco de uma categorização peremptória, uma consideração chama atenção: implementada sem diálogo (MORTATTI, 2019a), sem consulta e debate democrático, nos âmbitos de decisão da área da alfabetização, a PNA apresenta os moldes de uma política de governo e é partícipe de uma agenda interna calcada em um ideário ultraconservador e neoliberal.

De forma veemente, a PNA defende o método fônico de alfabetização, conhecido, no Brasil, desde, pelo menos, o século XIX. Na avaliação de Mortatti (2009), os métodos de alfabetização podem ser caracterizados de duas formas: sintético (da "parte" para o "todo") e analítico (do "todo" para a "parte"). A depender do que foi considerado o ponto de partida, ou seja, a unidade linguística a partir da qual se devia começar o ensino da leitura e da escrita; e também a depender do que se considerou "todo" ou "parte", na história da alfabetização brasileira, a seguinte subdivisão foi consolidada: a) métodos sintéticos, que incluem os métodos alfabético, fônico, silábico; e b) métodos analíticos, que abrangem a palavração, sentenciação, historieta, conto.

Gontijo (2005) observa que a Alfabetização tem caráter político, é um processo único e abrangente, que produz sentidos, e não está restrito a cerceamentos da fonética e da fonologia. Mortatti (2019a), por sua vez, adverte que a defesa do método fônico não é algo novo. A pesquisadora questiona a implementação de uma política como a PNA, em um contexto de subserviência de instâncias públicas aos interesses do mercado. A materialização da PNA esvazia a dimensão crítica da alfabetização e continua o projeto de subordinação da Educação Básica aos interesses privados (GONTIJO; ANTUNES, 2019); é uma ofensiva grave, um retrocesso, uma guinada (ideo)metodológica para trás e pela direita, cujos efeitos atendem a uma agenda neoliberal e ultraconservadora (MORTATTI, 2019a, 2019b).

Na seção O que direm os especialistas (BRASIL, 2019b), é no mínimo curiosa a citação de um excerto do Professor Roger Beard, do Instituto de Educação da University College London, especialista em alfabetização e um dos consultores da PNA:

\begin{abstract}
É, em geral, aceito em todo o mundo que um dos propósitos centrais da escola é ajudar os alunos a aprender a ler e a escrever, reconhecendo assim a contribuição da alfabetização para o crescimento pessoal mediante o uso eficiente da informação e a leitura de boa literatura. A alfabetização é considerada também promotora de valiosas formas de entender o mundo e a nós mesmos. Por isso uma alfabetização de má qualidade pode não apenas prejudicar os indivíduos, mas também afetar toda a economia nacional (BRASIL, 2019b, p. 16).
\end{abstract}

O fragmento salienta uma preocupação com a economia; todavia, não menciona as causas do analfabetismo no Brasil, um problema político, reflexo de uma realidade social e historicamente assentada pela injustiça (FREIRE, 1981; FERRARO, 2009). Trata-se de uma política de viés solipsista, na qual a leitura de "boa literatura" está associada ao "crescimento" pessoal. Nesse aspecto, é possível observar ao menos dois problemas. Um deles é pôr em relevo o aspecto individual da leitura literária. Em consonância com os estudos de Duarte (2001), a individualização e a consequente culpabilização do cidadão pelo seu sucesso ou fracasso são enunciados que eclipsam os problemas estruturais do Brasil e seguem o lastro de uma agenda neoliberal. Afinal, o 
"[...] neoliberalismo privatiza tudo, inclusive também o êxito e o fracasso social" (GENTILI, 1996, p. 6). Todorov (2009) salienta a infinitude de possibilidades de interação e de enriquecimento oriundas da leitura literária. Afinal somos seres inacabados, inconclusos, carentes do olhar do outro (BAKHTIN, 2011). Como acentua Todorov (2009), a literatura amplia a capacidade de olhar o mundo. Ela está longe de ser um entretenimento: porque um trabalho humano, aumenta a possibilidade de responder melhor ao processo de humanização. O segundo problema repousa na negação desse processo; ademais, reduzir a leitura literária ao aspecto individual é obliterar a dimensão solidária (DALVI, 2012) inerente a essa prática.

A PNA desconsidera as peculiaridades inerentes à alfabetização de crianças e à alfabetização de jovens e adultos (MACIEL; RESENDE, 2019). Com relação à literatura, é salientado que:

\begin{abstract}
Ao jovem e ao adulto que não sabem ler e escrever busca-se não apenas proporcionar autonomia para ler e escrever o próprio nome e algumas palavras relacionadas ao seu cotidiano, mas, além disso, apresentar a leitura e a escrita como meios de desenvolvimento pessoal e profissional, de acesso à literatura e de outras possibilidades, conforme as motivações e aspirações de cada pessoa. (BRASIL, 2019b, p. 35).
\end{abstract}

Na política neoliberal, é o mercado de trabalho que direciona as decisões concernentes à política educacional. No entanto, a educação não nutre uma relação direta com a garantia de emprego (SAVIANI, 2013; FRIGOTTO, 2015a). Ao contrário, nessa perspectiva, o sistema educacional se presta à "empregabilidade", entendida como a capacidade de ser flexível (e servil) às demandas do mercado. Ao defender-se uma educação devotada aos interesses mercadológicos e laborais, estimula-se a competitividade própria e defendida pelas corporações capitalistas. Nas condições apresentadas, a leitura e a escrita, propostas pela PNA, seguem tributárias de uma função pragmática, comprimidas a "meios de desenvolvimento", destinadas a fins individuais e competitivos. Nessa toada, ao jovem e ao adulto sobram, apenas, a aproximação, o "acesso" à literatura, conforme interesses particulares.

Além de não ser explicado como se daria esse "acesso", a proposição oculta as mazelas advindas de uma sociedade desigual, transformando a resolução de problemas de origem histórica, econômica e social em uma questão puramente individualista, reflexo de um "egoísmo produtivo" (FRIGOTTO, 2015b). Essa abordagem é coerente a um Estado mínimo, que, dentre outras práticas, restringe significativamente os direitos coletivos (IBARRA, 2011), dentre os quais se encontra a educação, resguardada na Constituição Federal de 1988 (BRASIL, 1988) e na Lei de Diretrizes e Bases da Educação Nacional (LDB) - Lei No 9.394, de 20 de dezembro de 1996 (BRASIL, 1996). Logo, a menção à literatura seguiu o coro: cumpriu uma função menor que ornamento no excerto supracitado.

A implementação da PNA, no $8^{\circ}$ artigo, inciso XI, está circunscrita a seguir:

Art. $8^{\circ}$ A Política Nacional de Alfabetização será implementada por meio de programas, ações e instrumentos que incluam: [...]

XI. incentivo à produção e à edição de livros de literatura para diferentes níveis de literacia [...]. (BRASIL, 2019b, p. 45).

Mortatti (2019a) pontua que a PNA se consubstancia em uma cruzada ideológica, cujo desígnio é eliminar/aniquilar inimigos "heréticos". Convém lembrar que regimes autoritários controlam e censuram a produção artística. Quando sugere o "[...] incentivo à produção e à edição de livros de literatura para diferentes níveis de literacia", a PNA erige uma cadeia depreciativa, pois: a) rechaça todo um vasto arcabouço literário que tem sido elaborado ao longo dos séculos, no Brasil e no mundo; b) ignora livros já enviados às escolas, custeados com dinheiro público, por meio do extinto Programa Nacional Biblioteca da Escola (PNBE). Esse programa também contava com a seção PNBE Temático que fornecia às escolas públicas obras sobre as temáticas diversidade,

Práxis Educativa, Ponta Grossa, v. 15, e2015264, p. 1-21, 2020 Disponível em: <https://www.revistas2.uepg.br/index.php/praxiseducativa> 
inclusão e cidadania; c) de igual modo, dista-se de políticas ainda em vigor, como é o caso do PNLD-Literário, que também prevê o envio de obras literárias às escolas; e d) desqualifica possíveis políticas de incentivo à leitura, instauradas por estados e municípios.

O documento define literacia como um conjunto de conhecimentos, de habilidades e de atitudes relacionados à leitura e à escrita, bem como sua prática produtiva. Pondera que a literacia pode se desenvolver em níveis distintos: desde o básico até o avançado (BRASIL, 2019b). A proposta de uma produção para atender aos vários níveis de literacia é também questionável, porque desconsidera que os problemas atinentes à educação repousam nas marcantes disparidades sociais brasileiras. As práticas neoliberais intensificam a desigualdade (CARNEIRO; GAMBI, 2018). Por isso, a aceitação dos vários níveis de literacia está afinada à conveniente aceitação da desigualdade social, que mantém, igualmente conveniente (e incólume), a distribuição de riquezas e de bens culturais no Brasil.

Para diferentes públicos, com necessidades distintas, o documento os reúne em um bloco único e ainda sugere:

O desenvolvimento de materiais didáticos próprios para a alfabetização na educação especial, na educação bilíngue de surdos e na educação escolar indígena também está no horizonte do Ministério da Educação, assim como a produção de livros de literatura, literatura surda, em Braille e em tinta e Braile. A PNA incentivará ainda as comunidades indígenas a produzirem literatura em língua indígena e bilíngue português/língua indígena, com temas da cultura dos próprios povos, para o atendimento de sua educação Escolar. (BRASIL, 2019b, p. 36).

A insistência na repetição dos vocábulos, "produção" (de livros) e "produzirem" (literatura), alude ao ideário fabril-produtivista. Quando o documento, sob a roupagem de preocupação com a diversidade, insere em seu vago "horizonte" a produção de livros de literatura, literatura surda, em Braille e em tinta Braille, bem como a produção de literatura em língua indígena e bilíngue português/língua indígena, nada mais faz do que desvalorizar e depreciar todas as obras pré-existentes que versam sobre a temática, e, com isso, ele tanto mantém como alimenta a chama da mercantilização.

$\mathrm{O}$ artigo $5^{\circ}$, inciso $\mathrm{V}$, das Diretrizes da PNA, prevê:

Art. $5^{\circ}$ Constituem diretrizes para a implementação da Política Nacional de Alfabetização: [...]

V. estímulo aos hábitos de leitura e escrita e à apreciação literária por meio de ações que os integrem à prática cotidiana das famílias, escolas, bibliotecas e de outras instituições educacionais, com vistas à formação de uma educação literária. (BRASIL, 2019b, p. 52).

O excerto não menciona quais as outras instituições educacionais serão incluídas no rol para a inserção da educação literária, mas permite inferir que a concepção de educação literária propõe o estímulo de hábitos de apreciação literária em diversas instâncias integrados em práticas cotidianas. Quanto a essa diretriz, é preciso ponderar que a experiência com a Literatura excede o cotidiano. Geraldi (2013) alerta que a educação, fundamentada em uma atividade estética, implica considerar os acabamentos provisórios de um futuro aspirado. "Sem futuro, somente se faz educação para o presente, para o mercado, para o consumo, para o emprego" (GERALDI, 2013, p. 27). Se não há um compromisso com a educação ética (e estética), a educação literária ficará restrita à resolução de problemas, ao imediato, ao apressado, ao dia a dia, à apreciação, à superficialidade.

Na PNA, a educação literária está disposta de modo mais nítido no fragmento a seguir: 
Outro meio poderoso no processo de alfabetização é a leitura, à qual se segue a prática da escrita (art. $\left.5^{\circ}, V\right)$. A leitura pode introduzir-se bem cedo na vida infantil, com histórias lidas em voz alta pelos pais, cuidadores ou professores; mais tarde, já alfabetizada e em fase de aquisição de fluência, a criança passa à leitura autônoma de textos cada vez mais complexos e começa a expressar por escrito suas impressões. O hábito da leitura é fundamental para que a criança venha a se tornar um leitor hábil. Devem atentar para isso sobretudo pais, cuidadores e professores, que estão em condição privilegiada de estimulá-lo. E, sendo a leitura um meio propício para ampliar o vocabulário, enriquecer a expressão oral e escrita, despertar a sensibilidade estética e o gosto pelos livros, nela se deve pôr todo o cuidado, seja na eleição do texto, seja na escolha do ambiente e da ocasião. A educação literária daí decorrente contribui para a formação do imaginário da criança e de sua visão de mundo. É preciso, pois, estimular os ambientes de leitura nas escolas, nas bibliotecas, em instituições culturais e no seio da própria família, a fim de que o ato de ler, e a respectiva fruição do texto literário, passe a integrar o cotidiano de toda criança, independentemente da condição socioeconômica. (BRASIL, 2019b, p. 4142).

Tal qual à citação anterior, é mencionada, reincidentemente, a relação das famílias na criação "do hábito da leitura", cuja importância é inegável e merece ser cultivada. Entretanto, embora ainda não tenha abrigo em legislação específica, o tema da homeschooling (um estreitamento do processo educacional) tem ganhado muita robustez no governo atual, especialmente pela reivindicação de famílias e por ser objeto de Projeto de Lei no Congresso Nacional e de apreciação no Supremo Tribunal Federal (CASAGRANDE; HERMANN, 2020). Trata-se de um projeto que ataca as instituições formais de ensino como espaço de socialização do conhecimento elaborado e, em conformidade com perspectivas religiosas fundamentalistas, ameaça o conceito de Educação Básica e põe em xeque o ideal de escola e educação pública, gratuita, obrigatória e laica (CECCHETTI; TEDESCO, 2020).

Não se nega que um leitor hábil se forme a partir do hábito. Todavia, a partir da assertiva, questiona-se qual espécie de hábito defende a PNA. A “[...] interação discursiva é a realidade fundamental da língua" (VOLÓCHINOV, 2017, p. 219); logo, não é admissível compreender a leitura como uma prática mecânica e decifradora de códigos e/ou cativa à ideia de meio para resolução de problemas cotidianos.

A retórica da PNA em torno dos estímulos é confusa e frágil: a) assim, cabe conjecturar a possibilidade de o documento favorecer a ideia de estímulos-reações, cuja reação/resposta/finalidade esperada, nesse caso, seria tão somente formação de leitores/as hábeis. No entanto, pergunta-se: Hábeis a quê? Hábeis como? Hábeis quando? Hábeis onde?; b) a depender das realidades econômicas, históricas, sociais, culturais e formativas, nem todas as pessoas responsáveis, elencadas pela PNA, são capazes de oferecer estímulos ${ }^{4}$ às crianças. No caso dos/as docentes, se não há uma formação pedagógica específica, para a educação literária; se não há

\footnotetext{
4 A concepção de estímulo referenciada neste momento vinca-se à perspectiva da Psicologia Histórico-Cultural. De acordo com Martins e Rabatini (2011), para Vygotsky, o trabalho atua como mediador do processo dialético de transformação da natureza em cultura social. A cultura, nesse sentido, objetiva-se nos signos ou instrumentos culturais, é produto do trabalho humano e expressão do processo histórico. Ao colocar em destaque a gênese social das funções superiores, Vygotsky refletiu sobre o conceito de interiorização, compreendido como o processo que transmuta formações externas em internas e, no centro desse processo, destaca a importância dos signos. Nessa concepção, o ato instrumental promove importantes mudanças no comportamento humano, visto que, entre o estímulo do ambiente e a resposta do sujeito, se interpõe o novo elemento designado signo. O signo opera como um estímulo de segunda ordem, como estímulo cultural, retroagindo sobre as funções psíquicas e transformando suas expressões espontâneas em volitivas. Nessa perspectiva, o psiquismo humano alcança um funcionamento qualitativamente superior e apto a se libertar tanto de determinismos biológicos quanto do contexto imediato de ação. Os signos se instituem como meios auxiliares para a solução de tarefas psicológicas e analogamente às ferramentas como instrumentos técnicos de trabalho. Logo, a mediação, nessa concepção, é a interposição que provoca transformações, possui intencionalidade socialmente construída e promove desenvolvimento (MARTINS; RABATINI, 2011).
}

Práxis Educativa, Ponta Grossa, v. 15, e2015264, p. 1-21, 2020 Disponível em: <https://www.revistas2.uepg.br/index.php/praxiseducativa > 
trânsito pelas esferas da atividade humana tocadas pela literatura, supõe-se que fica ainda mais difícil a possibilidade de mediação adequada a sujeitos menos experientes e em processo de desenvolvimento, pois a carência de conhecimentos consistentes impede o processo de mediação de educação literária (DALVI 2018a, 2018b); c) se o estímulo for entendido como sinônimo de um simples fomento à leitura nas escolas, bibliotecas, instituições culturais e na família, isso também é insuficiente, ainda mais se for feito de modo desarticulado; d) para formarem-se leitores, são necessárias ações contundentes. Apenas para se restringir a problematização ao âmbito das instituições escolares formais, é indispensável uma miríade de ações que englobam, no mínimo, não só políticas públicas livrescas (exclusivamente de oferta de livros), mas a efetivação de inúmeros procedimentos que perpassam, de modo inegociável, as seguintes ações: salários dignos, plano de carreira e condições decentes de trabalho aos/às professores/as e demais trabalhadores da educação; processo formativo consistente; espaços apropriados para a leitura com a disponibilização de bibliotecários/as; proposição de currículos e projetos pedagógicos que reconheçam a necessidade e a importância do tema; apoio das Secretarias de Educação, dentre tantos outros aspectos.

A PNA também afirma que a leitura é um meio favorável para expandir o vocabulário, enriquecer a expressão oral e escrita, despertar a sensibilidade estética e o gosto pelos livros. Estabelece, para tanto, a condicionante de que se deva "pôr todo o cuidado", seja na escolha do texto, seja na seleção do ambiente e da ocasião. Por certo, a leitura contempla todos esses aspectos, que não são inatos, e estão sujeitos às condições objetivas. Dependem do trabalho educativo, compreendido como o ato de produzir, de modo direto e intencional, em cada indivíduo singular, a humanidade que é produzida histórica e coletivamente pelo conjunto dos homens e das mulheres (SAVIANI, 2011). Isso implica tanto na identificação dos elementos culturais, que necessitam ser assimilados pelos indivíduos da espécie humana, para que se tornem humanos como, concomitantemente, a descoberta das formas mais apropriadas para atingir esse objetivo (SAVIANI, 2011). De igual modo, tal tarefa requer uma práxis qualificada. No entanto, diante da crescente perseguição e censura a obras literárias infantis e juvenis ${ }^{5}$, essa recomendação/condicionante também é vista com desconfiança.

O documento ainda salienta que a leitura e a fruição literária devem integrar o cotidiano de toda a criança, independentemente das questões econômicas. Todavia, no Brasil, a realidade a que milhares de crianças são submetidas desnuda qualquer discurso de independência entre condição socioeconômica e escola. Dados da Pesquisa Nacional por Amostra de Domićlios Contínua (PNAD Contínua), do Instituto Brasileiro de Geografia e Estatística (IBGE, 2019), ressaltam a conservação das brutais desigualdades socioeconômicas no Brasil, demonstradas, por exemplo, na concentração de renda, na manutenção de grande número de desempregados e trabalhadores na informalidade, problema mais agudizado na população preta/parda e, com relação ao gênero, nas mulheres. Na educação, apesar de ter havido um aumento no nível de instrução dos/as brasileiros/as, nos anos 2000, a pesquisa também destaca as desigualdades no acesso e na permanência na escola, bem como o fracasso escolar, acentuado em populações economicamente mais vulneráveis (IBGE, 2019). Esses dados confirmam a atualidade dos estudos de Patto (2015), cujos resultados evidenciaram uma "fracassalização" do/a estudante pauperizado/a: fenômeno administrado por um discurso naturalizante desse fracasso.

De acordo com o Instituto de Pesquisa Econômica Aplicada (Ipea), no ano de 2019, houve um aumento da desigualdade de renda no Brasil, acompanhado do predomínio da informalidade

${ }^{5}$ São exemplos de obras que foram perseguidas nos últimos anos: Enquanto o sono não vem, de José Mauro Brant; $O$ Diário de Anne Frank em HQ, de Ari Folman e David Polonsk; O Menino que espiava para dentro, de Ana Maria Machado; e Meninos sem pátria, de Luiz Puntel (BRASIL, 2017; ALVARENGA, 2018; ROCHA, 2018; BLOWER; GRANDELLE, 2018). 
(precarização do trabalho) e da lenta recuperação do mercado formal. No governo atual, de um lado, a população economicamente mais rica tem tido aumento em seus rendimentos e, de outro, as famílias mais pobres têm perdido renda, também por causa dos efeitos da inflação, vislumbrado em reajustes de produtos e serviços indispensáveis, tais como energia elétrica, tarifas de ônibus, alimentos e medicamentos (IPEA, 2019). O Índice Global de Mobilidade Social, publicado por uma instância que reúne os principais líderes (empresariais) do mundo, o Fórum Econômico Mundial, em janeiro de 2020, considera aspectos tais como acesso, qualidade e equidade da educação, saúde, proteção social, condições e oportunidade de trabalho, distribuição justa de salários, acesso à tecnologia, dentre outros aspectos, como pilares para mobilidade social. A pesquisa mostrou, por sua vez, que das 82 nações elencadas, o Brasil ocupou o $60^{\circ}$ lugar, tendo ficado atrás de países como Sri Lanka e México (WORLD ECONOMIC FORUM, 2020).

Nessa conjuntura, a concepção de educação literária da PNA é uma proposta fenecida, mutilada, diminuída à simples leitura de textos, sobretudo em duas instâncias: família e escola (nessa ordem). Ela consiste em prática reducionista, pois comprime a educação literária ao ensino de literatura e/ou à leitura literária (DALVI, 2018a, 2018b). Além de tímida, a proposição do MEC é simplista, pois estrutura-se em frágeis pilares de "acesso", "apreciação" e "estímulo". Nesse sentido, a PNA apenas abranda e solapa o potencial da Literatura; afinal, como enfatiza Candido (1988, p. 75): "A literatura confirma e nega, propõe e denuncia, apoia e combate, fornecendo a possibilidade de vivermos dialeticamente os problemas".

É na metáfora do elo que repousa a noção de "enunciado", que será produzido em um determinado contexto, em condições específicas de produção, com determinadas intenções e está integrado a enunciados antecedentes e posteriores, impossibilitando, dessa maneira, uma categorização rígida e estanque, como o último ou o primeiro elo dentro dessa cadeia (BAKHTIN, 2016). Considerando o enrijecimento de uma agenda neoliberal e ultraconservadora (que na educação são vislumbradas em práticas já mencionadas neste artigo), a educação literária forjada pela PNA, calcada no limitado "acesso", na "apreciação" fugaz, no aligeirado "estímulo" e na parca "fruição" da leitura literária, apresenta uma proposta acrítica, nutrida em uma retórica aparentemente panfletária.

O discurso supostamente inovador, divulgado na propaganda do Governo Federal, relativo à PNA, reforça a tese segundo a qual o enunciado é individual/único e está sujeito à "ênfase valorativa" (VOLÓCHINOV, 2017). Para esse autor, essa ênfase está atrelada aos sentidos adquiridos por uma palavra em diversos contextos de uso. Desse modo, a PNA, cujo documento não menciona uma única obra literária, imersa em um contexto de acirramento da desigualdade social, de posturas antidemocráticas, usa a diretriz da educação literária como um eco das artimanhas neoliberais, perpetradas pelo Governo Federal.

O uso do termo educação literária em campos tão opostos insta uma diferenciação. Como não poderia ser diferente, na PNA, o conceito em nada se aproxima das concepções de educação literária defendida por Leahy-Dios (2004), Colomer (2007) e Dalvi (2018a, 2018b, 2018c), anunciadas no início deste trabalho. Em nítido negacionismo, a PNA não propõe uma educação para a criticidade, rumo à conscientização do sujeito sobre o lugar que ele ocupa na produção da sua existência, também por meio do texto literário; não prevê, além disso, nenhuma confrontação de como foram instaurados as ideias e os valores historicamente produzidos na cultura. E, por fim, não sugere defrontar os sujeitos com a complexidade humana possibilitada pelo literário, tampouco visa a formar sujeitos para a transformação da realidade produtora de miséria social.

No ensaio As ideias fora do lugar, Schwarz (2014) afirma que: "Ao longo de sua reprodução social, incansavelmente o Brasil põe e repõe ideias europeias, sempre em sentido impróprio. É nesta qualidade que elas serão matéria e problema para a literatura” (SCHWARZ, 2014, p. 62). A

Práxis Educativa, Ponta Grossa, v. 15, e2015264, p. 1-21, 2020 Disponível em: <https://www.revistas2.uepg.br/index.php/praxiseducativa> 
partir da análise de textos machadianos, o autor evidencia a contradição de um país atravessado pelo genocídio indígena, pelo trabalho e pelo sangue derramado por homens e mulheres negras no período escravocrata. Concomitantemente, esse mesmo país procurava, nos moldes do liberalismo europeu, ideias indescartáveis e impossíveis de serem aplicadas em sua plenitude. Desse modo, resguardadas as devidas proporções, parece que, no início do século XXI, com relação à leitura literária em políticas oficiais de alfabetização, as ideias ainda "permanecem fora do lugar". Quer seja pela redução da leitura literária ao deleite (Profa, Pró-Letramento e Pnaic), quer seja na proposta de corrosão da educação literária na PNA, objeto de discussão deste artigo. Ainda de acordo com Schwarz (2014, p. 58): "O escravismo desmente as ideias liberais". A PNA, inserida em um contexto de solidificação das desigualdades, pautada por uma agenda iníqua, ultraconservadora e neoliberal, desmente, portanto, a própria noção de educação literária. Se há renúncia a elementos fulcrais como justiça social, democracia, e à própria Literatura, não há como se defender $a$ educação literária.

Diante do exposto, parece urgente relembrar princípios basilares de um "clássico sobre educação literária" (DALVI, 2019), o ensaio O direito à literatura, de Antonio Candido. O autor afirma que a literatura está presente em todos os povos, aparece claramente como manifestação universal. No entanto, adverte que, mesmo nessas condições, a literatura é uma necessidade que precisa ser satisfeita, pois, talvez, sem ela, não haja equilíbrio social. Como um direito humano incompressível, ela nos humaniza, contribui com o processo formativo omnilateral (CANDIDO, 1988). Dalvi (2018c) assevera que a educação literária de verdade não se faz com a aposta em políticas públicas que insistam na manutenção de privilégios e na concentração de renda. Assegura, ainda, que: "Não é possível pensar em educação literária ou em ensino de literatura fora do campo educacional e não é possível desentranhar a educação das relações econômicas, sociais, políticas e culturais amplas" (DALVI, 2018c, p. 24). Dessa maneira, mesmo que a PNA apresente uma diretriz de educação literária, por ser um pilar de uma política pública neoliberal, ela fragiliza a possibilidade de uma educação literária crítica e, portanto, priva, sobretudo sujeitos em processo de alfabetização, de um direito inalienável: a Literatura (CANDIDO, 1988).

\section{Considerações finais}

Este artigo visou a refletir como a diretriz de educação literária é abordada na Política Nacional de Alfabetização (PNA) e em que medida se configura como uma concepção afim ao ideário neoliberal gestor de sua implementação. Em seu percurso, este texto mostrou que essa política de governo (OLIVEIRA, 2011), fundada em voluntarismo ideológico (CUNHA, 1991), rechaça os avanços democráticos e, em uma volta à direita, parece marchar, de coturnos, pelo menos até o século XIX (MORTATTI, 2019a, 2019b), berço do método fônico de alfabetização.

Afirmar que a PNA consiste em uma política pública neoliberal pode soar incongruente, afinal ser neoliberal implica o achatamento do Estado. Contudo, a partir dos dados analisados e em consonância com Ibarra (2011), o intervencionismo estatal é visto como beneplácito pelo neoliberalismo, pois a mão visível do Estado precisa delas para assegurar a prevalência do mercado. Diante desse imbróglio, é necessário confessar certo constrangimento de, em pleno século XXI, ter de falar não sobre o ensino de conhecimentos atinentes ao literário por exemplo, mas, dadas as exigências contemporâneas, que incluem a nitidez de uma casta orgulhosa de sua ignorância e que não se constrange com a miséria alheia, reiterar: $a$ educação literária não se ampara no enrijecimento das desigualdades, não visa à solidificação da pobreza. Educação literária, de fato, não se funda no autoritarismo, pois ele corrói a própria noção de educação e de literatura.

Candido (1988) admite que a literatura tem um papel formador da personalidade. Nas mãos do/a leitor/a, ela pode ser um risco. No âmbito da educação escolar, pondera o autor, pode gerar 
conflitos, porque transcende as normas estabelecidas. Bakhtin (2016) afirma que todo enunciado é prenhe de reposta. Tal assertiva permite entrever que os silêncios, as ausências, as lacunas também são respostas. Quando a PNA apresenta como diretriz um simulacro de educação literária, ela não o faz por ingenuidade; a destreza recai justamente na proposição de uma diretriz volátil que assegure a constância das normas, a contumácia da injustiça e o distanciamento do "risco" de que falou Candido (1988). Afinal, uma política pública educacional, ao renunciar ao literário, abandona, por consequência, o ensino, o debate, a mediação, a disposição de tempo e de investimento público para leitura, pesquisa e formação imperativos a esse campo de conhecimento; e, também, chancela, em âmbito institucional, o afastamento, desde o início do processo de escolarização, de uma "necessidade universal" (CANDIDO, 1988).

Essa conclusão torna-se ainda mais visível, quando se toma o decreto que extingue as bolsas do CNPq para pesquisa (Pibic) na área das Humanidades (citadas no início deste artigo) como exemplo. Tal medida pode acarretar ao menos dois movimentos, igualmente nefastos. Se um arremedo de educação literária é apresentado, abdica-se da necessidade de investimento de dinheiro público para pesquisas que versam sobre o tema. As universidades são ancoradas na indissociabilidade da tríade ensino, pesquisa e extensão. Contudo, é na pesquisa que elas têm o ponto fundamental de sustentação de suas outras duas tarefas (SEVERINO, 2002). Nesse caso, o processo formativo de docentes, o diálogo da universidade com a comunidade bem como o desenvolvimento de pesquisas na contramão do cenário apresentado podem ficar severamente comprometidos.

A cada programa de alfabetização brasileiro, são anunciados os mesmos problemas (analfabetismo, lamentáveis resultados de avaliações de larga escala, necessidade de formação de professores/as). A maneira de suspostamente solucioná-los fincam-se em ideias supostamente inovadoras, sem, contudo, se resolver as questões de distribuição igualitária de renda, taxação das grandes fortunas, reforma agrária, respeito aos direitos humanos, preservação do meio ambiente, igualdade racial e de gênero, por exemplo. Desse modo, cumpre salientar que a diretriz de educação literária proposta pela PNA é coerente com o ideário neoliberal, na medida em que contribui para a manutenção das injustiças sociais, foge das práticas democráticas necessárias à implementação de uma política pública educacional, ataca os elementos para a qualidade da escola pública, trata a leitura como algo pragmático e de viés puramente individualista e, se não afasta, ao menos diminui a possibilidade de educação em diálogo com a estética.

Na obra O Processo, Franz Kafka (com k) narra a vida Josef K., vítima de um sistema impetuoso, controlador. Ao acordar, a personagem é presa sem qualquer explicação. Na urgência de não sermos acometidos/as pelo mesmo final da protagonista, cabe mencionar duas perspectivas. Frigotto (2015b) avalia que, na esfera educacional, mais grave que a expansão do mercado privado é a imposição de uma concepção mercantil no conteúdo, método e forma da educação pública. Essa realidade algoz, segundo o autor, demanda urgentemente uma agenda que retome o espaço público como única possibilidade, mesmo que restrita, de garantia de direitos. Para Mortatti (2019b), o enfrentamento da PNA concretizar-se-á a partir de ações de resistência; a autora conclama, duplamente, a desobediência civil e reiteração de um amplo debate público, rumo à defesa da educação pública, laica e gratuita, bem como do Estado Democrático de Direito. Para tão grande tarefa, a literatura, um direito inalienável (CANDIDO, 1988), é mais que necessária. Caso contrário, com licença a Millor Fernandes e à poeta Beatriz Azevedo, é render-se a este Brasil, o país do Future-se, com um grande passado pela frente. 


\section{Referências}

ALVARENGA, P. Versão em quadrinhos de O Diário de Anne Frank causa polêmica em escola de Vitória. G1 Espírito Santo, Vitória, 29 mar. 2018. Disponível em: <https://g1.globo.com/es/espirito-santo/noticia/versao-em-quadrinhos-de-o-diario-de-annefrank-causa-polemica-em-escola-de-vitoria.ghtml>. Acesso em: 29 mar. 2018.

ANDES. Sindicato Nacional dos Docentes das Instituições de Ensino Superior. Orçamento da Educação sofre corte de $\mathbf{R} \$ \mathbf{5 , 8 3}$ bilhões. 2019. Disponível em: $<$ https://www.andes.org.br/conteudos/noticia/orcamento-da-educacao-sofre-corte-de-r-5-83bilhoes1\#>. Acesso em: 1 maio 2019.

ANDRADE, H. de. Bolsonaro reduz vagas e murcha participação social em conselhos. Uol, Brasília, 18 jul. 2019. Disponível em: <https://noticias.uol.com.br/politica/ultimasnoticias/2019/07/26/bolsonaro-reduz-vagas-emurcha-participacao-social-em-conselhosrecriados.htm>. Acesso em: 19 jul. 2019.

BAKHTIN, M. M. Estética da criação verbal. 6. ed. São Paulo: Martins Fontes, 2011.

BAKHTIN, M. M. Problemas da poética de Dostoiévski. Tradução Paulo Bezerra. 5. ed. Rio de Janeiro: Forense Universitária, 2013.

BAKHTIN, M. M. Teoria do Romance I: a estilística. Tradução, prefácio, notas e glossário de Paulo Bezerra. São Paulo: Editora 34, 2015.

BAKHTIN, M. M. Os gêneros do discurso. Tradução, Posfácio e Notas de Paulo Bezerra. São Paulo: Editora 34, 2016.

BASILIO, A. L. Por que os cursos de Filosofia e Sociologia incomodam Bolsonaro? Carta Capital, São Paulo, 26 abr. 2019. Disponível em: $<$ https://www.cartacapital.com.br/educacao/por-que-os-cursos-de-filosofia-e-sociologiaincomodam-bolsonaro/>. Acesso em: 29 abr. 2019.

BLOWER, A. P.; GRANDELLE, R. Colégio Santo Agostinho, do Rio, suspende uso de livro considerado 'comunista' por grupo de pais. O Globo, Rio de Janeiro, 2 out. 2018. Disponível em: $<$ https://oglobo.globo.com/sociedade/colegio-santo-agostinho-do-rio-suspende-uso-de-livroconsiderado-comunista-por-grupo-de-pais-23122273 >. Acesso em: 3 out. 2018.

BOGHOSSIAN, B. Ministro reage a protestos com delírio totalitário e perseguição. Folha de São Paulo, São Paulo, 31 maio 2019. Disponível em: <https://www1.folha.uol.com.br/colunas/bruno-boghossian/2019/05/ministro-reage-aprotestos-com-delirio-totalitario-e-perseguicao.shtml>. Acesso em: 29 jun. 2019.

BRASIL. [Constituição (1988)]. Constituição da República Federativa do Brasil. Brasília, DF: Senado, 1988.

BRASIL. Lei No 9.394, de 20 de dezembro de 1996. Estabelece as diretrizes e bases da educação nacional. Brasília: Presidência da República, Casa Civil, Subchefia para Assuntos Jurídicos, [1996]. Disponível em: <http://www.planalto.gov.br/ccivil_03/leis/19394.htm>. Acesso em: 24 jul. 2019. 
BRASIL. Decreto $\mathbf{N}^{\text {o }}$ 7.559, de 1 de setembro de 2011. Dispõe sobre o Plano Nacional do Livro e Leitura - PNLL e dá outras providências. Brasília: Presidência da República, Casa Civil, Subchefia para Assuntos Jurídicos, [2011]. Disponível em: <http://www.planalto.gov.br/ccivil_03/_ato2011-2014/2011/decreto/d7559.htm>. Acesso em: 24 jul. 2019.

BRASIL. Emenda Constitucional No 95, de 15 de dezembro de 2016. Altera o Ato das Disposições Constitucionais Transitórias, para instituir o Novo Regime Fiscal, e dá outras providências. Diário Oficial da União: seção 1, Brasília, DF, n. 241, p. 2-3, 16 dez. 2016.

BRASIL. Ministério da Educação. Assessoria de Comunicação Social. Com base em parecer técnico, MEC recolhe das escolas o livro 'Enquanto o sono não vem'. Ministério da Educação, Brasilia, 2017. Disponível em: <http://portal.mec.gov.br/ultimas-noticias/211218175739/50011-mec-recolhe-das-escolas-o-livro-enquanto-o-sono-nao-vem>. Acesso em: 9 jul. 2017.

BRASIL. Ministério da Educação. Secretaria de Educação Continuada, Alfabetização, Diversidade e Inclusão. Apresentação. 2018. Disponível em: <http://portal.mec.gov.br/secretaria-deeducacao-continuada-alfabetizacao-diversidade-e-inclusao/apresentacao $>$. Acesso em: 18 mar. 2019.

BRASIL. Decreto $\mathbf{N}^{\circ} \mathbf{9 . 7 6 5}$, de 11 de abril de 2019. Institui a Política Nacional de Alfabetização. Brasília: Presidência da República, Casa Civil, Subchefia para Assuntos Jurídicos, [2019a]. Disponível em: <http://www.planalto.gov.br/ccivil_03/_Ato20192022/2019/Decreto/D9765.htm>. Acesso em: 3 ago. 2019.

BRASIL. Ministério da Educação. Secretaria de Alfabetização. PNA: Política Nacional de Alfabetização. Brasília: MEC, SEALF, 2019b. Disponível em: <http://portal.mec.gov.br/images/CADERNO_PNA_FINAL.pdf>. Acesso em: 13 fev. 2020.

BRASIL. Decreto $\mathbf{N}^{\circ} \mathbf{9 . 9 3 0}$, de 23 de julho de 2019. Altera o Decreto n. 7.559, de $1^{\circ}$ de setembro de 2011, que dispõe sobre o Plano Nacional do Livro e Leitura. Brasília: Presidência da República, Casa Civil, Subchefia para Assuntos Jurídicos, [2019c]. Disponível em: <http://www.planalto.gov.br/ccivil_03/_ato2019-2022/2019/decreto/D9930.htm>. Acesso em: 24 jul. 2019.

BRASIL. Ministério da Educação. Assessoria de Comunicação Social. Perguntas e respostas do Future-se, programa de autonomia financeira do ensino superior. Ministério da Educação, Brasília, 2019d. Disponível em: <http://portal.mec.gov.br/component/content/article?id=78351>. Acesso em: 20 jul. 2019.

BRASIL. Portaria No 34, de 9 de março de 2020. Dispõe sobre as condições para fomento a cursos de pós-graduação stricto sensu pela Diretoria de Programas e Bolsas no País da CAPES. 2020. Diário Oficial da União: seção 1, Brasília, DF, n. 53, p. 45, 18 mar. 2020a.

BRASIL. Coordenação de Comunicação Social do CNPq. Ministério da Ciência, Tecnologia, Inovações e Comunicações. Iniciação Científica: nova chamada. 2020b. Disponível em: <http://www.cnpq.br/web/guest/noticiasviews/-

/journal_content/56_INSTANCE_a6MO/10157/8920772>. Acesso em: 29 abr. 2020. 
BRASIL. Portaria No 1.122, de 19 de março de 2020. Define as prioridades, no âmbito do Ministério da Ciência, Tecnologia, Inovações e Comunicações (MCTIC), no que se refere a projetos de pesquisa, de desenvolvimento de tecnologias e inovações, para o período 2020 a 2023. Diário Oficial da União: seção 1, Brasília, DF, n. 57, p. 19, 24 mar. 2020c.

BRASIL. Portaria $\mathrm{N}^{\circ} 1.329$, de 27 de março de 2020. Altera a Portaria no 1.122 , de 19 de março de 2020, que define as prioridades, no âmbito do Ministério da Ciência, Tecnologia, Inovações e Comunicações (MCTIC), no que se refere a projetos de pesquisa, de desenvolvimento de tecnologias e inovações, para o período 2020 a 2023. Diário Oficial da União: seção 1 - Extra, Brasília, DF, n. 61-A, p. 1, 30 mar. 2020d.

CANDIDO, A. O direito à literatura. In: CANDIDO, A. Vários Escritos. São Paulo: Duas Cidades, 1988. p. 169-191.

CARNEIRO, A. P.; GAMBI, T. F. R. Neoliberalismo, desigualdade e democracia: discussão fundamentada nos conselhos econômicos e sociais. Revista Cadernos de Gestão Pública e Cidadania, São Paulo, v. 23, n. 74, p. 69-88, jan./abr. 2018. DOI: http://dx.doi.org/10.12660/cgpc.v23n74.68697

CARTA CAPITAL. Abraham Weintraub fala "limpar" livros didáticos. Carta Capital, São Paulo, 2. mar. 2020. Disponível em: <https://www.cartacapital.com.br/educacao/abraham-weintraubfala-em-limpar-livros-didaticos>. Acesso em: 02 abr. 2020.

CASAGRANDE, C. A.; HERMANN, N. Formação e homeschooling: controvérsias. Práxis Educativa, Ponta Grossa, v. 15, e2014789, p. 1-16, 2020. DOI: https://doi.org/10.5212/PraxEduc.v.15.14789.032

CECCHETTI, E.; TEDESCO, A. L. Educação Básica em "xeque": Homeschooling e fundamentalismo religioso em tempos de neoconservadorismo. Práxis Educativa, Ponta Grossa, v. 15, e2014816, p. 1-17, 2020. DOI: https://doi.org/10.5212/PraxEduc.v.15.14816.026

COLOMER, T. Andar entre livros. São Paulo: Global, 2007.

CUNHA, L. A. Educação, estado e democracia no Brasil. São Paulo: Cortez, 1991.

DALVI, M. A. Ensino de Literatura: algumas contribuições. In: UYENO, E. Y.; PUZZO, M. B.; RENDA, V. L. B. S. (Orgs.). Linguística aplicada, linguística e literatura: intersecções profícuas. Campinas: Pontes, 2012. p. 15-43.

DALVI, M. A. Educação literária: história, formação e experiências. In: DALVI, M. A. (Org.). Literatura e educação: história, formação e experiência Campos dos Goytacazes, RJ: Brasil Multicultural, 2018a. p. 12-24.

DALVI, M. A. Formação de leitores e educação literária: uma base que desaba. Voz da Literatura, Brasília, v. 7, n. 7, p. 13-17, nov. 2018b.

DALVI, M. A. Políticas públicas para educação literária: nem públicas, nem literárias? In: BRANDILEONE, A. P. N.; OLIVEIRA, V. S. (Orgs.). Literatura na escola: contextos e práticas em sala de aula. Campinas: Pontes, 2018c. p. 23-38. 
DALVI, M. A. Um clássico sobre educação literária: “o direito à literatura”, de Antonio Candido. Via Atlântica, São Paulo, n. 35, p. 221-234, 2019. DOI: https://doi.org/10.11606/va.v0i35.154687

DUARTE, N. Vigotski e o “aprender a aprender”: crítica às apropriações neoliberais e pósmodernas da teoria vigotskiana. 2. ed. Campinas: Autores Associados, 2001.

El PAÍS. Ministro promete mudar livros didáticos por "visão mais ampla" da ditadura. E1 País, 3 abr. 2019. Disponível em: <https://brasil.elpais.com/brasil/2019/04/04/politica/1554334968_202816.html>. Acesso em: 6 abr. 2019.

ESTADÃO CONTEÚDO. MEC contraria discurso e congela verba da educação básica, além das faculdades. Estadão, São Paulo, 4 maio 2019. Disponível em: $<$ https://www.em.com.br/app/noticia/nacional/2019/05/04/interna_nacional,1051153/meccontraria-discurso-e-congela-verba-da-educacao-basica-alem-das-fa.shtml $>$. Acesso em: 5 maio 2019.

FERRARO, A. R. História inacabada do analfabetismo no Brasil. São Paulo: Cortez, 2009.

FOLHA DE SÃO PAULO. "Brasileiro viajando é canibal", diz ministro da Educação a revista. Folha de São Paulo, 1 fev. 2019. Disponível em: $<$ https://www1.folha.uol.com.br/educacao/2019/02/brasileiro-viajando-e-canibal-diz-ministroda-educacao-a-revista.shtml>. Acesso em: 3 fev. 2019.

FREIRE, P. Ação cultural para a liberdade. 5. ed. Rio de Janeiro: Paz e Terra, 1981.

FRIGOTTO, G. Contexto e sentido ontológico, epistemológico e político da inversão da relação educação e trabalho para trabalho e educação. Revista Contemporânea de Educação, Rio de Janeiro, v. 10, n. 20, p. 228-248, 2015a. DOI: https://doi.org/10.20500/rce.v10i20.2729

FRIGOTTO, G. A produtividade da escola improdutiva 30 anos depois: regressão social e hegemonia às avessas. Revista Trabalho Necessário, Niterói, v. 13, n. 20, p. 206-233, 2015b. DOI: https://doi.org/10.22409/tn.13i20.p8619

GENTILI, P. Neoliberalismo e educação: manual do usuário. 1996. Disponível em: $<$ https://barricadasabremcaminhos.files.wordpress.com/2010/06/neoliberalismo-eeducacao.pdf $>$. Acesso em: 13 abr. 2020.

GERALDI, J. W. Bakhtin tudo ou nada diz aos educadores: os educadores podem dizer muito com Bakhtin. In: FREITAS, M. T. A. (Orgs.). Educação, Arte e Vida em Bakhtin. Belo Horizonte: Autêntica Editora, 2013. p. 11-28.

GONTIJO, C. M. M. Alfabetização e a questão do letramento. Cadernos de Pesquisa em Educação, Vitória, v. 1, p. 42-72, 2005.

GONTIJO, C. M. M. Alfabetização: políticas mundiais e movimentos nacionais. Campinas, SP: Autores Associados, 2014. 
GONTIJO, C. M. M.; ANTUNES, J. S. C. Diálogos com o Plano Nacional de Alfabetização (2019): contrapalavras. Revista Brasileira de Alfabetização, Florianópolis, v. 1, n. 10, p. 32-38, jul./dez. 2019.

IBARRA, D. O neoliberalismo na América Latina. Brazilian Journal of Political Economy, v. 31, n. 2, p. 238-248, abr./jun. 2011. DOI: https://doi.org/10.1590/S0101-31572011000200004

IBGE. Coordenação de População e Indicadores Sociais. Síntese de indicadores sociais: uma análise das condições de vida da população brasileira 2019. Rio de Janeiro, 2019. Disponível em: <https://biblioteca.ibge.gov.br/visualizacao/livros/liv101678.pdf>. Acesso em: 3 abr. 2020.

IPEA. Seção VIII: Mercado de Trabalho. Carta de Conjuntura do Instituto de Pesquisa Econômica Aplicada. $2020 . \quad$ Disponível em: <http://www.ipea.gov.br/portal/images/stories/PDFs/conjuntura/190918_cc_44_mercado_de _trabalho.pdf>. Acesso em: 3 abr. 2020.

LEAHY-DIOS, C. Educação literária como metáfora social: desvios e rumos. São Paulo: Martins Fontes, 2004.

MACIEL, F. I. P.; RESENDE, V. B. de. Alfabetização de jovens e adultos na Política Nacional de Alfabetização. Revista Brasileira de Alfabetização, Florianópolis, v. 1, n. 10, p. 129-133, jul./dez. 2019.

MARIZ, R.; FERREIRA, P. Decisão de Vélez sobre alfabetização é questionada por integrantes do Inep. O Globo, 26 mar. 2019. Disponível em: $<$ https://oglobo.globo.com/sociedade/educacao/decisao-de-velez-sobre-alfabetizacaoquestionada-por-integrantes-do-inep-23551386>. Acesso em: 27 mar. 2019.

MARTINS, L. M.; RABATINI, V. G. A concepção de cultura em Vigotski: contribuições para a educação escolar. Revista Psicologia Política, São Paulo, v. 11, n. 22, p. 345-358, 2011.

MIGUEL, L. F. Folha se une a Bolsonaro na defesa da privatização das universidades. DCM, 21 maio 2019. Disponível em: <https://www.diariodocentrodomundo.com.br/folha-se-une-abolsonaro-na-defesa-da-privatizacao-das-universidades-por-luis-felipe-miguel/>. Acesso em: 22 jul. 2019.

MORENO, A. C. MEC prioriza método fônico e alfabetização aos 6 anos, mas aceita que ciclo só termine aos $8 . \quad$ G1. 11 abr. 2019. Disponível em: <https://g1.globo.com/educacao/noticia/2019/04/11/mec-prioriza-metodo-fonico-e-

alfabetizacao-aos-6-anos-mas-aceita-que-ciclo-so-termine-aos-9.ghtml>. Acesso em: 12 maio 2019.

MORTATTI, M. do R. L. A “querela dos métodos" de alfabetização no Brasil: contribuições para metodizar o debate. Revista Eletrônica Acolhendo a Alfabetização nos Países de Língua Portuguesa, São Paulo, v. 3, n. 5, p. 91-114, 2009. DOI: https://doi.org/10.11606/issn.19807686.v3i5p91-114

MORTATTI, M. do R. L. Brasil, 2091: Notas sobre a "política nacional de alfabetização". Olhares, Salvador, v. 7, n. 3, p. 17-51, 2019a. DOI: https://doi.org/10.34024/olhares.2019.v7.9980 
MORTATTI, M. do R. L. A "Política Nacional de Alfabetização" (Brasil, 2019): uma "guinada" (ideo)metodológica para trás e pela direita. Revista Brasileira de Alfabetização, Florianópolis, v. 1, n. 10, p. 26-32, jul./dez. 2019b.

MORTATTI, M. do R. L. Um balanço crítico da "Década da Alfabetização" no Brasil. Cadernos Cedes, Campinas, v. 33, n. 89, p. 15-34, 2013. DOI: https://doi.org/10.1590/S0101$\underline{32622013000100002}$

MUGNATTO, S. Ministro quer rever metas do Plano Nacional de Educação. 2019. Disponível em: <https://www2.camara.leg.br/camaranoticias/noticias/EDUCACAO-ECULTURA/576934-MINISTRO-QUER-REVER-METAS-DO-PLANO-NACIONAL-DEEDUCACAO.html>. Acesso em: 1 jun. 2019.

NICOLETI, T. Balbúrdia na ortografia. Folha de São Paulo, São Paulo, 30 ago. 2019. Disponível em: <https://thaisnicoleti.blogfolha.uol.com.br/2019/08/30/balburdia-na-ortografia/>. Acesso em: 3. abr. 2020.

OLIVEIRA, D. A. Das políticas de governo à política de Estado: reflexões sobre a atual agenda educacional brasileira. Educação \& Sociedade, Campinas, v. 32, n. 115, p. 323-337, 2011. DOI: http://dx.doi.org/10.1590/S0101-73302011000200005

PALHARES, I. Na contramão do discurso oficial, MEC congela R $\$ 2,4$ bi da educação básica. $\mathbf{O}$ Estado de São Paulo, São Paulo, 4 maio 2019. Disponível em: $<$ https://educacao.estadao.com.br/noticias/geral,na-contramao-do-discurso-oficial-meccongela-r-2-4-bi-da-educacao-basica,70002815259>. Acesso em: 5 maio 2019.

PATTO, M. H. de S. A produção do fracasso escolar: histórias de submissão e rebeldia. São Paulo: Intermeios, 2015.

PERA, G. MEC lança caderno da Política Nacional de Alfabetização. 2019. Disponível em: $<$ http://portal.mec.gov.br/ultimas-noticias/211-218175739/79101-mec-lanca-caderno-dapolitica-nacional-de-alfabetizacao $>$. Acesso em: 9 mar 2020.

PINHO, A.; SALDAÑA, P.; GENTILE, R. Gestão Bolsonaro faz corte generalizado em bolsas de pesquisa no país. Folha de São Paulo, São Paulo, 8 maio 2019. Disponível em: <https://www1.folha.uol.com.br/educacao/2019/05/gestao-bolsonaro-faz-corte-generalizadoem-bolsas-de-pesquisa-pelo-pais.shtml>. Acesso em: 9 maio 2019.

RAMALHETE, M. P. Leitura literária em programas governamentais de formação de professores alfabetizadores do início do século XXI (2001-2018): o tropeço, a trapaça e o deleite. 2019. 205 f. Tese (Doutorado em Educação) - Centro de Educação, Universidade Federal do Espírito Santo, Vitória, 2019.

REVISTA FÓRUM. MEC encerra programa de intercâmbio de línguas do Governo Federal. 2019. Disponível em: <https://revistaforum.com.br/mec-encerra-programa-deintercambio-delinguas-do-governo-federal/>. Acesso em: 21 jul. 2019.

ROCHA, L. Deputado acusa livro infantil de "induzir" crianças ao suicídio. Campo Grande News, Campo Grande, 16 set. 2018. Disponível em: 
$<$ https://www.campograndenews.com.br/politica/deputado-acusa-livro-infantil-de-induzircriancas-ao-suicidio $>$. Acesso em: 27 set. 2018.

RONZANI, S. Homeschooling: à direita volver. Le Monde Diplomatique, São Paulo, 13 mar. 2019. Disponível em: <https://diplomatique.org.br/homeschooling-a-direita-volver/>. Acesso em: 3 abr. 2019.

SALDAÑA, P. Vélez exalta igreja e família e diz que MEC vai combater marxismo cultural. Folha de São Paulo, São Paulo, 2 jan. 2019. Disponível em: $<$ https://www1.folha.uol.com.br/educacao/2019/01/velez-exalta-igreja-e-familia-e-diz-quemec-vai-combater-marxismo-cultural.shtml>. Acesso em: 3 fev. 2019.

SAVIANI, D. Desafios da construção de um sistema nacional articulado de educação. Trabalho, Educação e Saúde, Rio de Janeiro, v. 6, n. 2, p. 213-232, 2008. DOI: https://doi.org/10.1590/S1981-77462008000200002

SAVIANI, D. Sistema nacional de educação articulado ao plano nacional de educação. Revista Brasileira de Educação, Rio de Janeiro, v. 15, n. 44, p. 380-392, 2010. DOI: https://doi.org/10.1590/S1413-24782010000200013

SAVIANI, D. Pedagogia histórico-crítica: primeiras aproximações. 11. ed. Campinas, SP: Autores Associados, 2011.

SAVIANI, D. Política educacional brasileira: limites e perspectivas. Revista de Educação PUCCampinas, Campinas, n. 24, p. 7-16, jun. 2012.

SAVIANI, D. História das ideias pedagógicas. 4. ed. Campinas: Autores Associados, 2013.

SCHWARZ, R. As ideias fora do lugar: ensaios selecionados. São Paulo: Companhia das Letras, 2014.

SEVERINO, A. J. Metodologia do trabalho científico. 22. ed. São Paulo: Cortez editora, 2002.

TODOROV, T. A literatura em perigo. Tradução de Caio Meira. Rio de Janeiro: DIFEL, 2009.

VOLÓCHINOV, V. N. A construção da enunciação e outros ensaios. Tradução e Notas João Wanderley Geraldi. São Carlos: Pedro \& João Editores, 2013.

VOLÓCHINOV, V. N. Marxismo e filosofia da linguagem: problemas fundamentais do método sociológico na ciência da linguagem. Tradução, notas e glossário Sheila Grillo e Ekaterina Vólkova Américo. São Paulo: Editora 34, 2017.

WORLD ECONOMIC FORUM. Global Social Mobility Index 2020: why economies benefit from fixing inequality. 2020. Disponível em: <http://www3.weforum.org/docs/Global_Social_Mobility_Report.pdf >. Acesso em: 6 abr. 2020

Recebido em 06/05/2020

$V$ ersão corrigida recebida em 20/05/2020

Aceito em 22/05/2020

Publicado online em 29/05/2020

Práxis Educativa, Ponta Grossa, v. 15, e2015264, p. 1-21, 2020

Disponível em: < https://www.revistas2.uepg.br/index.php/praxiseducativa> 